\title{
Phenology, seed dispersal and difficulties in natural recruitment of the canopy tree Pachira quinata (Malvaceae)
}

\author{
Maria Clara Castellanos ${ }^{1,2}$ \& Pablo R. Stevenson ${ }^{1}$ \\ 1. Centro de Investigaciones Ecológicas La Macarena, Universidad de Los Andes. Cr. 1 no. 18 -12. Bogotá, Colombia; \\ pstevens@uniandes.edu.co \\ 2. Centro de Investigaciones sobre Desertificación (CSIC-UV-GV), Apartado Oficial, 46470 Albal, Valencia, Spain; \\ maclacas@uv.es
}

Received 17-VIII-2010. Corrected 10-XII-2010. Accepted 10-I-2011.

\begin{abstract}
Life history and recruitment information of tropical trees in natural populations is scarce even for important commercial species. This study focused on a widely exploited Neotropical canopy species, Pachira quinata (Malvaceae), at the southernmost, wettest limit of its natural distribution, in the Colombian Amazonia. We studied phenological patterns, seed production and natural densities; assessed the importance of seed dispersal and density-dependent effects on recruitment, using field experiments. At this seasonal forest $P$. quinata was overrepresented by large adult trees and had very low recruitment caused by the combination of low fruit production, high seed predation and very high seedling mortality under continuous canopies mostly due to damping off pathogens. There was no evidence of negative distance or density effects on recruitment, but a clear requirement of canopy gaps for seedling survival and growth, where pathogen incidence was drastically reduced. In spite of the strong dependence on light for survival of seedlings, seeds germinated readily in the dark. At the study site, the population of $P$. quinata appeared to be declining, likely because recruitment depended on the rare combination of large gap formation with the presence of reproductive trees nearby. The recruitment biology of this species makes it very vulnerable to any type of logging in natural populations. Rev. Biol. Trop. 59 (2): 921-933. Epub 2011 June 01.
\end{abstract}

Key words: anemochory, damping off, density-dependence, emergent tree, Bombacopsis quinata, seedling survival, Tinigua National Park.

Many tropical timber tree species get a particularly high share of damage, because in addition to the destruction of their habitats due to deforestation, they are selectively logged in areas where their native forests are still standing (Nepstad et al. 1999, Asner et al. 2005). If the species are also cultivated, then they are not in risk of going extinct, strictly speaking. But extraction practices of highly valued species can seriously threaten wild populations, or even lead to local extinction, and to the genetic impoverishment this entails (André et al. 2008). Because target species are usually large and long-lived trees, they are likely to play important ecological roles in the forest and their overexploitation could have additional negative consequences to other plant and animal species.

In spite of their commercial and ecological importance, it is surprising how little is known about the life history and requirements for recruitment of many timber species in their natural habitats, even if they are widely logged or cultivated (Guariguata \& Pinard 1998, Schulze et al. 2008b). Tropical tree species occur in low densities and recent studies show that some of them have stringent requirements for recruitment in their native habitats, and are therefore very sensitive to disturbance (Lobo et al. 2007, Schulze et al. 2008a, Schulze et al. 
2008b). This is likely the case for many other species, but basic life history information in wild populations is scarce.

In this study we report several aspects of the natural recruitment of Pachira quinata (Jacq.) W.S. Alverson (Malvaceae), an endangered canopy tree species native to Central America and northern South America. Its populations have been extensively logged throughout its natural range (Kane et al. 1993, Sandiford 1998, Pérez et al. 2004). The species is also cultivated for timber production in Colombia, Venezuela, and Central America, and in some regions, it represents the most important timber species (Kammesheidt 1998, Cordero \& Boshier 2003). The requirements for growing this species are therefore well known (see Cordero \& Boshier 2003 for a recent monograph). A few studies have focused on its biology in natural forests, covering phenological aspects, pollination and reproductive efficiency, often in fragmented landscapes (Quesada et al. 2001, Fuchs et al. 2003, Lobo et al. 2003). Other aspects remain mostly unstudied in natural habitats. For a population at the southern, wettest limit of its distribution, we describe phenological patterns, seed production and dispersal, germination, natural densities and assess the importance of seed dispersal and density-dependent effects on recruitment using field experiments. Our results contribute to the knowledge of early recruitment of tropical canopy trees and potential density-dependence effects, and highlight the sharp contrast between the low recruitment of this species in native forests compared to the ease with which it is cultivated for timber.

\section{MATERIALS AND METHODS}

\section{Study species and site}

Pachira quinata (=Bombacopsis quinata) inhabits dry forests of Central and South America, and extends to the south into moist, but seasonal, forests at the lowland regions close to the eastern slopes of the Andes. It does not occur in the adjacent non-seasonal Amazonian forests. It is a deciduous tree that produces bat- and moth-pollinated flowers after leaf abscission. It presents a mixed mating system with outcrossing rates that depend on the number of available mates (Fuchs et al. 2003). The fruits are loculicid capsules with small seeds (ca. $4 \mathrm{~mm}$ in length) surrounded by a kapok that favors dispersal by wind. In their natural forests, adults become large emergent trees. The wood is strong, resistant to termite attacks and easy to handle (Kane et al. 1993, Pérez et al. 2004); therefore, it is valuable for construction and for production of a variety of woodcrafts.

This study took place at the Centro de Investigaciones Ecológicas La Macarena $\left(2^{\circ}\right.$ $40^{\prime} \mathrm{N}, 74^{\circ} 10^{\prime} \mathrm{W}$; 350-400m a.s.l), within Tinigua National Park, a rain forest at the border between the upper Amazon and Orinoco basins of Colombia. Rainfall is seasonal with a dry period between January and March and a mean annual rainfall of $2780 \mathrm{~mm}$ (Stevenson et al. 2008). The study site includes both terra firme and flooded forests (Stevenson et al. 2004). Human intervention at the study site was limited to two small patches of 4-6ha, which were cleared and then abandoned and were mostly covered by grasses or secondary forest at the time of this study.

\section{Phenology}

To describe phenological patterns, we made biweekly observations on six marked trees during one year (August 1996-July 1997), and recorded the presence (or absence) of flowers, fruits and leaves in each tree. In addition, we looked for intra-annual variability in phenology using $5.6 \mathrm{~km}$ of transects, which we revisited biweekly during three years (August 1996-July 1997, January-December 2000, January-December 2001). We recorded the presence of flowers or fruits in all trees on transects and then estimated among-individual synchronization following the vector method adapted by Stevenson et al. (2008). 


\section{Estimation of crop size}

To estimate fruit and seed production, we made direct counts of fruits with binoculars in six adult trees (as in Chapman et al. 1994) in February 1996, right before fruit ripening, when trees have lost their leaves. Seed production was estimated by multiplying the number of fruits in a crown by the average number of seeds per fruit $(51 \pm 37.6$ seeds per fruit, $n=35$ healthy undehisced fruits found on the floor, most likely knocked down by fruit predator birds). We also estimated flower production indirectly from 16-24 traps with a basal area of $0.08 \mathrm{~m}^{2}$ installed on the floor underneath the crowns of three of the six adult trees, haphazardly distributed, for the whole reproductive season. We recorded floral buds and open flowers in the traps and from this and the approximate crown cover, estimated the number of aborted and viable flowers in each tree.

\section{Seed shadows}

Three $P$. quinata trees were chosen to determine the spatial location of the dispersed seeds with reference to the parent tree. The chosen trees had no other adult individuals around, to avoid overlap in the seed shadows. Four $3 \mathrm{~m}$-wide transects were established in the four cardinal directions starting at the base of the trunk. The down-wind transect was $100 \mathrm{~m}$ long and the others were $50 \mathrm{~m}$ long. We monitored transects biweekly and registered both individually-dispersed seeds (conspicuous thanks to the surrounding kapok), and those that fell inside the fruit, but were viable (had normal shape and hardness). For each seed we registered the distance to the parental tree. Seeds were left where they were found, but the kapok was removed to avoid recounting the seeds later.

\section{Distance from parent tree and density dependence in seed predation}

An experimental latin squares design was used to examine the effect of three different factors on the predation of seeds: seed density, dispersal distance and local density of parental trees. Seeds (with kapok) were placed on the floor at five different distances from a parental tree: 2, 10, 20, 50 and $100 \mathrm{~m}$, in the down-wind direction. In each location the density of seeds was $1,2,4,16$ or 50 , according to the latin square design. We chose these numbers because seeds can be dispersed individually or in small groups, while high densities of seeds are also found in fruits that fall before dehiscence and open on the forest floor. We repeated this experiment under four different trees varying in the number of conspecific adult trees around them. We chose one tree with no other P. quinata trees around, one with one neighbor in a radius of $100 \mathrm{~m}$, a third surrounded by four trees, and a last one that was part of a group of 17 adult conspecific tress in one hectare. A fifth group of seeds was established in an area with no $P$. quinata trees, as a control. The experiment started on the first week of March, just after the fruits were ripen in the forest, and monitored biweekly until the first week of April. The dependent variable measured was the percentage of seeds removed, assuming that missing seeds had been predated. We analyzed the results of the first week of the experiment only, because seed predation was highest in this period and germination started soon after. Percentage data were arc-sin transformed with the Freeman \& Tuckey adjustment (Zar 1996).

\section{Germination success}

We experimentally tested the effect of the forest light environment on seed germination. Light was controlled by placing seeds in petri dishes with $15 \mathrm{~mL}$ water in three different types of forest: closed canopy, open canopy and light gap. A fourth group was placed in the darkness as a control. The seeds had been collected previously from different trees and stored in a dry container. Treatments were replicated four times and germination rates checked every three days for three weeks, and then compared with ANOVA. The experiment was set up in late March and early April, when most seeds germinated in the forest. 


\section{Early establishment of seedlings and sapling survival}

Seedling survival was monitored in six $3 \mathrm{~m}$-wide understory transects, each running $100 \mathrm{~m}$ down-wind from a parent tree. We labeled all seedlings found within transects during the first week of April, when germination rates were highest in the forest and then monitored the survival of every seedling weekly during the following three months. Newly germinated seedlings were included during the first two weeks; after that time no germination was observed. As controls, we labeled and monitored 15 seedlings in the forest floor that were found more than $100 \mathrm{~m}$ away from a possible parental tree. We assigned mortality to fungal infection ("damping off"), herbivory, mechanical damage (i.e., litterfall or uprooting), or unknown causes. Seedlings affected by damping off pathogens were recognized by the characteristic symptoms of initial necrosis of the stem close to the ground, darkening leaves and leaf fall. From the information obtained in these transects we determined the distribution of seedlings relative to the parental tree and also recorded the main causes of mortality and their relative importance, the death rate through time and the effect on seedling mortality of the distance to the parental tree. Because of the very low density of seedlings in transects, results for all transects were clumped for the analyses.

In addition, we transplanted groups of 20 seedlings to different light conditions to determine the effect of light availability on survival. Four groups of seedlings were transplanted to each of three different light conditions: close canopy, open canopy and light gap. Four additional groups of seedlings were transplanted to gaps located within the range of seed dispersal of a parental P. quinata. For this experiment, we collected healthy seedlings from different trees and mixed them in the different treatments. Replicates were set in different sites in the forest, within $1 \mathrm{~m}^{2}$ plots. All seedlings were monitored for survival every week. ANOVAS were used to compare between groups.
To assess two-year survival in two forest types, four groups of 30 seedlings of $P$. quinata were planted in May 1994. Two groups were planted in two locations under closed canopy forest, and two in similarly-sized grasslands in abandoned farms. We recorded survival and growth of the saplings two years after transplant.

\section{Natural density and grouping patterns}

The natural density of adults and saplings with a diameter at breast height $(\mathrm{DBH})>1 \mathrm{~cm}$ in the forest was determined in a census based on linear transects (Burnham et al. 1980), and in additional vegetation plots summing up to 7 ha. The census consisted of slowly walking a total of $21 \mathrm{~km}$ of trails throughout the forest $(17.5 \mathrm{~km}$ in non-floodable forest, $2.5 \mathrm{~km}$ in flooded forest and $1 \mathrm{~km}$ in secondary forest) and recording all individuals of $P$. quinata, easily recognized by their dark brown buttressed thorny trunk. Each tree was labeled and its DBH estimated. Trees with a DBH higher than $30 \mathrm{~cm}$ were considered adults. The perpendicular distance between each tree and the transect was measured in order to determine the actual width of the transect using King's method (Robinett et al. 1974), where transect width is given by the average distance of the trees to the transect. This is an appropriate estimation if the frequency of observed trees is close to a straight line that declines as the distance from the transect decreases, as was the case in our study. The density of trees was calculated as the number of individuals observed in the total area sampled (Area=length of transect*2*width). Considering only adult trees, transect width was $20 \mathrm{~m}$ and the total area sampled was $84 \mathrm{ha}$. The detection distance for saplings was truncated at $2 \mathrm{~m}$, and the total area sampled was 8.4ha.

We established five 1-ha plots to determine the presence of $P$. quinata individuals (one in flooded forests and four in terra firme forests) and an additional area of one ha was sampled in each forest with smaller plots (0.1 and $0.01 \mathrm{ha})$. To determine if the trees were grouped in space, we calculated Lloyd's aggregation index (Lloyd 1967), using 1-ha plots. We looked 
for saplings $(1-5 \mathrm{~cm} \mathrm{DBH})$ in 463 small plots $\left(25 \mathrm{~m}^{2}\right)$, within 1-ha plots. Finally, seedling $(\mathrm{DBH}<1)$ density was determined in $4 \mathrm{~m}^{2}$ plots nested within sapling plots. Twenty five of these plots were located in gaps.

\section{RESULTS}

\section{Phenology}

At Tinigua, $P$. quinata blooms and sheds all the leaves at the end of the rainy season and during the dry period (Fig. 1). Phenological patterns were similar across all years, with some variation in the onset and duration of flowering. Trees in transects produced flowers between August and January 1990-1991, October and March 1996-1997, and October and February in the two remaining years (20002001, 2001-2002). In all study years flowering of individual trees was highly synchronized (vector length $r>0.79$ for all years in a scale of $0-1$ of increasing synchrony, $\mathrm{p}<0.001$, Stevenson et al. 2008). Fruit ripening occurred between February and April in all years, in the transition from the dry to the wet season.

\section{Seed crops}

We found small fruit crops in general and large variations in the number of fruits and seeds produced among trees (1 to 108 fruits, roughly between 50 and 5500 seeds per tree, $\mathrm{n}=6$ trees). Low production of fruits and seeds was related to the low transition rates from flowers to fruits $(1.1 \% \pm 0.4 \mathrm{SD}$ of flowers turned into fruits, on average) and from flower buds to open flowers $(21 \% \pm 11 \mathrm{SD}$ on average). There was no correlation between fruit crop size and tree crown area $\left(r_{s}=0.6, p=0.67, n=6\right)$, or with flower production $\left(\mathrm{r}_{\mathrm{s}}=0.5, \mathrm{p}=0.67\right.$, $\mathrm{n}=3$ ). We observed strong pre-dispersal seed predation by psittacid birds (mainly Brotogeris cyanoptera, but also Ara species) and by unidentified curculionid beetles, both on ripe and unripe fruits. In general, pathogen attack was the main cause of seed mortality, particularly when seeds were dispersed within fruits. We also occasionally saw small rodents (e.g., Oecomys bicolor) consuming dispersed seeds of P. quinata.

\section{Seed shadows}

Most dispersed seeds (84\%) were found in the downwind direction ( $\mathrm{SE}$ transect), so we consider only that transect for each tree in this analysis. The distribution of viable seeds in transects was well described by a negative exponential distribution $\left(\mathrm{F}_{1,7}=53.2, \mathrm{r}^{2}=0.88\right.$, $\mathrm{p}=0.001$ ), generated by the large number of seeds within fruits landing below parental trees, between 5 and $10 \mathrm{~m}$ from the trunk $(76 \%$, $\mathrm{n}=317$, Fig. 2a). Excluding these, the distribution of individually-dispersed seeds also fit an exponential distribution $\left(\mathrm{F}_{1,7}=28.8\right.$, $\left.\mathrm{r}^{2}=0.8, \mathrm{p}=0.001\right)$, but in this case the mode

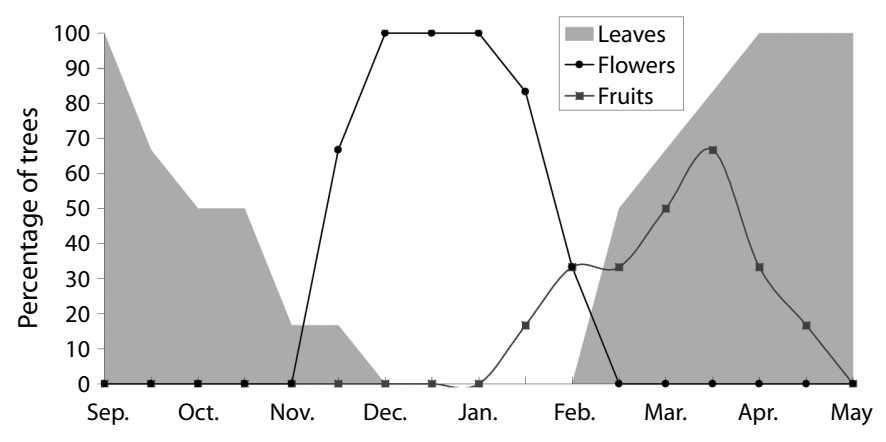

Fig. 1. Phenology of Pachira quinata at Tinigua National Park during the first study year, based on six trees. 

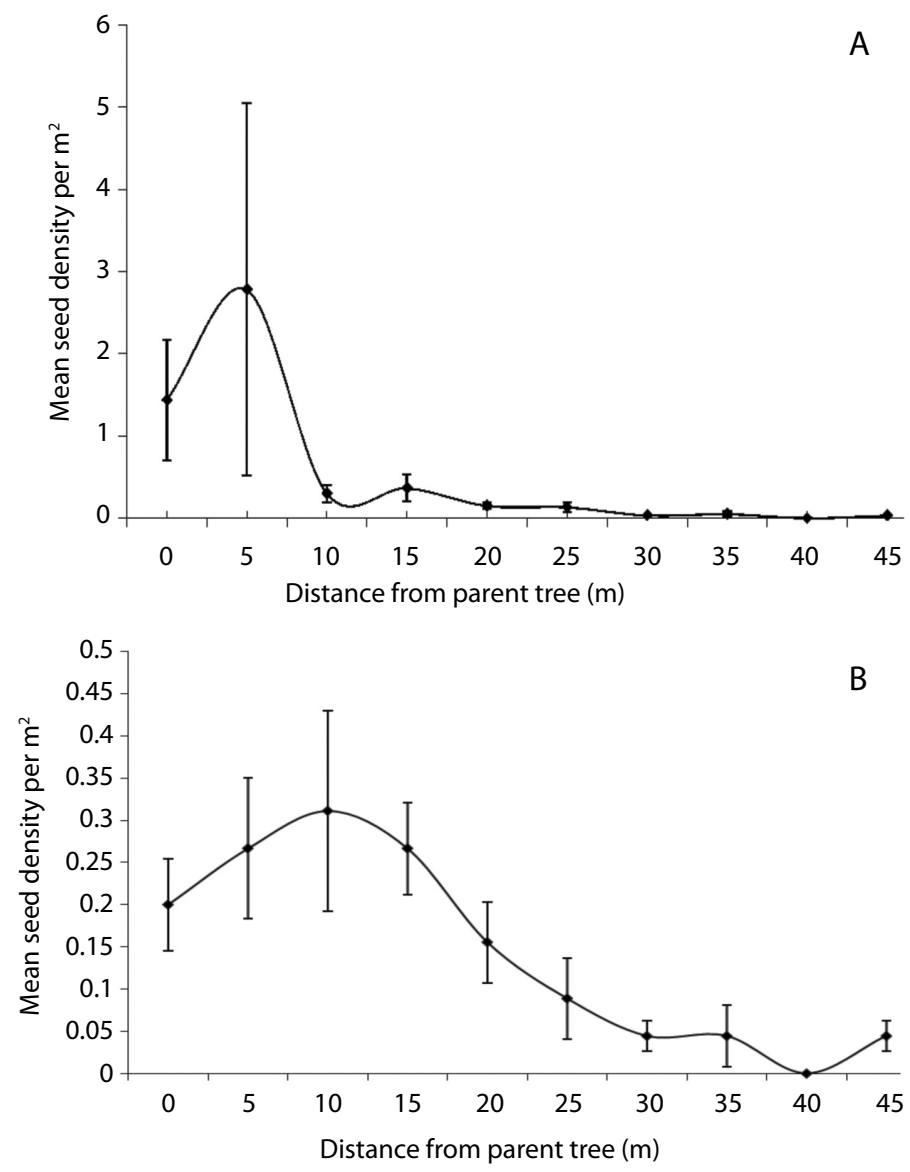

Fig. 2. Natural seed shadows around parental trees of Pachira quinata. (A) Mean number of all viable seeds at 5-m intervals, including those that fall within undehisced fruits, for three adult trees. (B) Includes only individually-dispersed seeds with kapok. Error bars are standard errors.

was between 10 and $15 \mathrm{~m}$ from the parental trunk (Fig. 2b). The tail of the distribution reached $50 \mathrm{~m}$.

\section{Distance from the parent tree and density-dependant seed predation}

Seed removal from experimental stations was not related to distance $\left(\mathrm{f}_{4,12}=0.88, \mathrm{p}=0.5\right)$, seed density $\left(\mathrm{F}_{4,12}=1.81, \mathrm{p}=0.19\right)$ or adult density $\left(\mathrm{F}_{4,12}=2.27, \mathrm{p}=0.12\right)$. We found some evidence of lower removal in places of high seed production: $24.6 \%(n=20)$ of the seeds were removed from locations with high density of trees, while $53.6 \%(n=30)$ were removed in places of low tree density.

\section{Seed germination}

The light environment did not affect seed germination rates $\left(\mathrm{F}_{3,48}<1.5, \mathrm{p}=0.2\right)$, or the speed of germination ( $f_{3,44}=0.93, p=0.43$ ). In fact, light was not necessary to induce germination, as seeds also germinated in the dark. Results did not vary after six days of the experiment, suggesting that viable $P$. quinata seeds germinate soon after they enter in contact with water. 


\section{Early seedling establishment}

\section{Seedlings on transects}

The natural distribution of seedlings downwind from parental trees followed a negative exponential distribution (Fig. 3, $\mathrm{f}_{(1,5)}=37.6$, $\mathrm{r}^{2}=0.88, \mathrm{p}=0.002$, for the linear regression of the log of number of seedlings on distance). Seedling mortality in transects was very high; $98 \%$ of seeds $(n=179)$ died within three months. We were able to establish the cause of mortality in $68 \%$ of the cases. At least between 44 and $69 \%$ of the seedlings in transects died

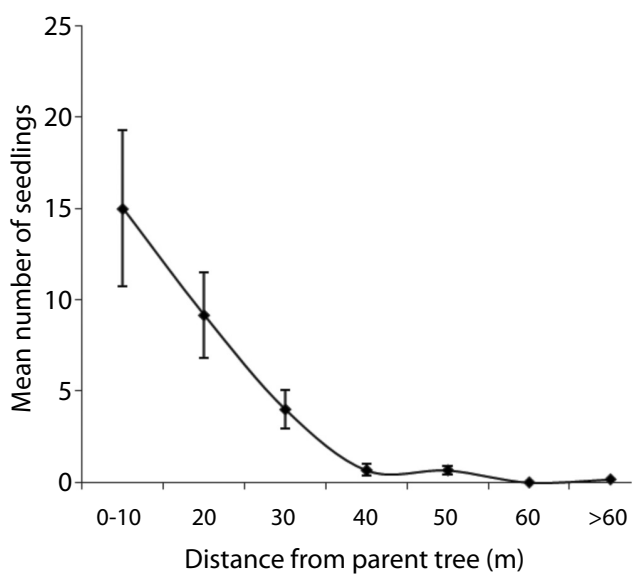

Fig. 3. Seedling distribution around parental trees of Pachira quinata. Points are mean number of seedlings $( \pm \mathrm{SE})$ in down-wind transects from six adult trees. because of damping off pathogens; control seedlings away from parental trees died for the same causes in a similar proportion (Table 1). Orthoptherans were the most evident herbivores and killed up to $27 \%$ of the seedlings in transects. We did not find a difference in seedling mortality rates at different distances form parental trees $\left(\mathrm{k}-\mathrm{w}\right.$ anova $\mathrm{h}_{(0.05)}=1.5$, $\mathrm{p}=0.82, \mathrm{df}=4$ ), suggesting that pathogens and herbivores affect seedlings independently from distance effects.

\section{Seedling transplants to gaps}

Seedling survival in forest gaps was higher than under continuous canopy (Kaplan Meier test: $\mathrm{X}^{2}=83.3, \mathrm{p}<0.001$ ), and was similar in gaps close and far from parental trees $\left(\mathrm{X}^{2}=1.37, \mathrm{p}=0.24\right)$. Survival in open-canopy forest showed intermediate levels (Fig. 4). Pathogen attack was the main mortality cause in gaps, but the number of seedlings dying from fungal attack was lower in gaps than under continuous canopies $(\mathrm{u}<0.001, \mathrm{p}=0.02, \mathrm{n}=8)$ and herbivory was higher in gaps (Table 2).

\section{Two-year survival}

Sapling survival after 2 years of transplant was very high for plants transplanted to grasslands (59 of 60 individuals), whereas only one of 60 survived under closed canopy conditions. For trees growing in the grasslands growing rates were between 0.55 and $1.90 \mathrm{~m}$

TABLE 1

Rates and causes of seedling mortality in natural conditions, monitored in transects around parental trees

\begin{tabular}{lcccccccc} 
& \multicolumn{9}{c}{ Transect } & \multicolumn{2}{c}{ Total } & Control $^{1}$ \\
& 1 & 2 & 3 & 4 & 5 & 6 & 179 & 15 \\
Number of seedlings & 36 & 31 & 13 & 30 & 18 & 51 & 179 & 100 \\
\% of dead seedlings & 100 & 90 & 100 & 100 & 100 & 98 & 98 & \\
Cause of death & & & & & & & & \\
Damping off (\%) & 64 & 68 & 69 & 50 & 44 & 46 & 55 & 47 \\
Herbivory (\%) & 6 & 11 & 0 & 7 & 17 & 18 & 11 & 13 \\
Uprooting and litterfall (\%) & 3 & 0 & 8 & 0 & 0 & 2 & 2 & 0 \\
Unknown (\%) & 27 & 21 & 23 & 43 & 37 & 34 & 32 & 40
\end{tabular}

1. Control seedlings were planted away from any parental tree. 


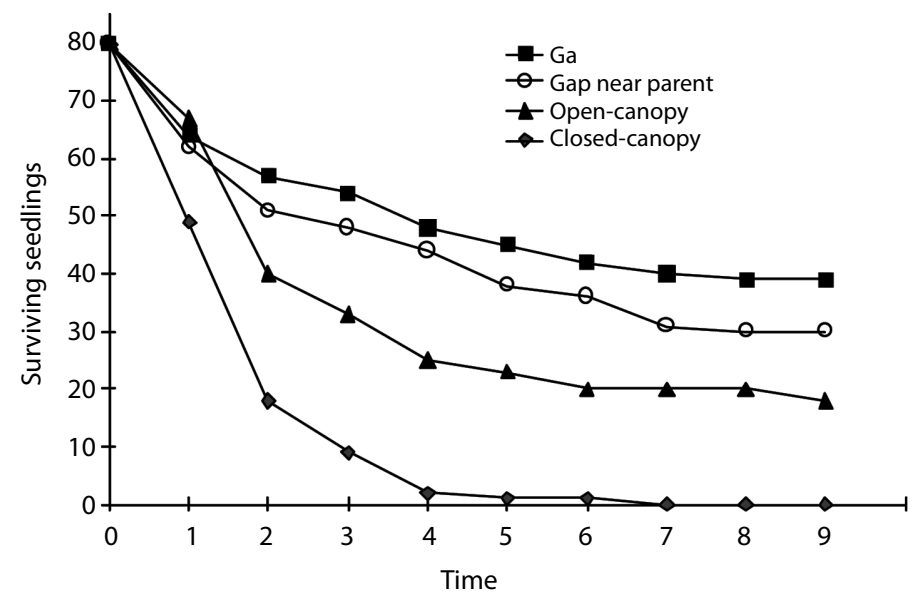

Fig. 4. Survival of transplanted seedlings under different light availability regimes.

TABLE 2

Rates and causes of mortality of seedlings transplanted to different forest types and gaps. Each treatment included 4 replicate locations with 20 seedlings each

$\begin{array}{lcccc} & \text { Closed-canopy } & \text { Open-canopy } & \text { Gap } & \text { Gap close to parent tree } \\ \text { Mean number of dead seedlings }( \pm \mathrm{SD}) & 20.0 \pm 0 & 15.5 \pm 2.4 & 10.3 \pm 1.7 & 12.5 \pm 2.4 \\ \text { Mean number of dead seedlings due to: } & & & & 6 \pm 1.5 \\ \text { Damping off } & 9 \pm 1 & 6.5 \pm 1.6 & 4.5 \pm 0.9 & 6 \pm 0.6 \\ \text { Herbivory } & 3.5 \pm 0.3 & 3.0 \pm 0.7 & 4.3 \pm 0.9 & 0.5 \pm 0.3 \\ \text { Uprooting and litterfall } & 0 & 0 & 0 & 3 \pm 1.2\end{array}$

per year for the first two years of development. The modal height for saplings in grasslands was between 1.5 and $2 \mathrm{~m}$, and maximal height was about $5 \mathrm{~m}$. The only surviving sapling under closed canopy reached about $0.5 \mathrm{~m}$ high after two years.

\section{Natural density and grouping patterns}

\section{Adult trees}

We observed high spatial variation in adult tree abundance in our census, ranking from 0 to 12 individuals/ha (overall density was ca. 0.77 trees/ha). The population consisted mainly of large individuals (DBH mode ca. $140 \mathrm{~cm}$ ), reaching up to $250 \mathrm{~cm}$ in $\mathrm{DBH}$ (Fig. 5). We

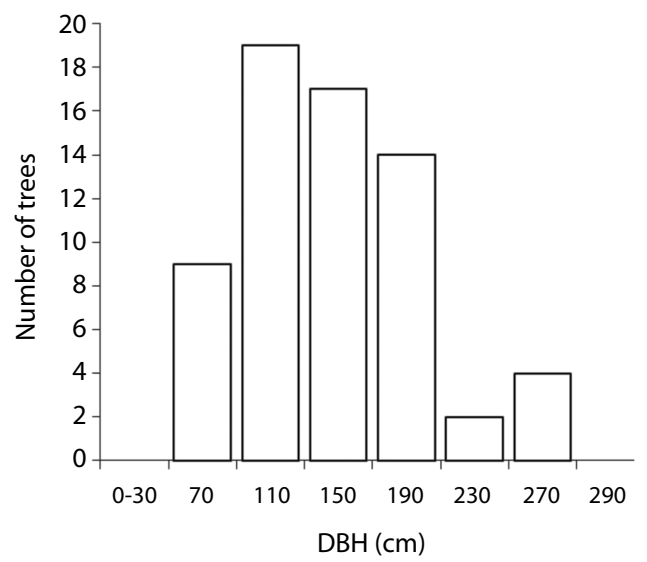

Fig. 5. Size distribution of tree size found in our census of the study population. Bars include tress with diameter at breast height $(\mathrm{DBH})$ in $40 \mathrm{~cm}$ intervals. 
did not find P. quinata trees in flooded forests. Young trees (DBH $5-15 \mathrm{~cm}$ ) were present only in secondary forests (i.e., abandoned farmland), with a density of 12.5 individuals/ha. We found three $P$. quinata trees in our 1-ha plots, yielding a mean density of 0.4 trees/ha $( \pm 0.5 \mathrm{SD})$. Loyd's index of aggregation was 4.9, confirming a strongly clumped distribution and the consequent local variation in tree abundance.

\section{Saplings and seedlings}

We did not find saplings in any of the 463 plots $\left(25 \mathrm{~m}^{2}\right)$, nor along transects throughout the forest. Similarly, we only found one seedling in $4 \mathrm{~m}^{2}$ plots, and this was located in a gap near a parental tree. Although it is not possible to provide accurate estimates from these plots, it seems likely that the average density of saplings is far less than one sampling per ha.

\section{DISCUSSION}

Our results picture a population of $P$. quinata represented mostly by adult trees and with very low recruitment. Below we discuss our findings and their implication for the distribution of the species and the management of natural populations.

\section{Phenology and the geographical distribution of $P$. quinata}

Several sources of evidence suggest that phenological patterns of $P$. quinata are regulated by rainfall. We found strong synchronization in phenological patterns among individual trees in our study area and a clear annual peak of flower production during the dry season. A previous correlative study suggested that flowering in $P$. quinata in our study area was associated with photoperiod changes, but flowering episodes were also related to the cumulative number of dry days, suggesting that lack of precipitation may be responsible for the onset of flowering (Stevenson et al. 2008). There is also a strong correlation between flower production and leaf fall, which in turn has been associated with water deficit in P. quinata (Gutiérrez-Soto et al. 2008). The intra-annual variation in the onset and length of flowering in our study site further suggests that the proximate factor regulating flowering in this species is precipitation and not photoperiod. Flowering of $P$. quinata takes place shortly after the onset of the dry season also in dry forests further north (Palo Verde, Costa Rica: Lobo et al. 2003; Guanacaste Conservation Area, Costa Rica: Quesada et al. 2001; Colombian Caribbean: Urueña \& Rodríguez 1988). In contrast, Lobo et al. (2003) found that flowering in two other bombacaceus species was not directly related to rainfall, because flowering dates coincided in two distant locations differing in rainfall regimes (Chamela in Mexico and Guanacaste in Costa Rica). This is not the case for P. quinata, because flowering dates in our population do not coincide with the Costa Rican populations (see also Fuchs et al. 2003), and in both locations follow after the onset of the rainy season.

No geographical barriers separate $P$. quinata from Amazonian forests further south from our study area, and yet the species is absent from those regions, where aseasonal forests prevail. The results of our study suggest two possible reasons that could contribute to the absence of this species from these forests. First, because flowering is triggered by rainfall following a dry period, it is possible that the lack of abiotic phenological triggers in non-seasonal environments prevents the colonization by $P$. quinata. Second, we also found that damping off pathogens were the most important cause of seedling mortality, but their effect was less strong in gaps, where conditions are less favorable for fungal attack. Given the potential for a higher incidence of pathogens in humid environments (Givnish 1999), it is possible that $P$. quinata has a low chance of survival in aseasonal forests compared to dry or seasonal forests.

\section{Population structure and recruitment}

We found a population of $P$. quinata overrepresented by adult trees, similar to other 
unlogged populations of the species (Kammesheidt 1998, Moret et al. 2008), and with very low recruitment caused by a combination of factors. A major one is that natural fruit production was quite limited and highly variable. We found even lower flower-fruit transitions $(1.1 \%)$ than in other studies of $P$. quinata (6-50\%: Quesada et al. 2001, Fuchs et al. 2003, Ramírez et al. 2008). In our study site, fruits are heavily attacked by predators (psittacid birds and curculionid beetle larvae). Fruit set could also be limited by low levels of outcross pollination in this low-density population, if bat pollinators do not fly from tree to tree or defend one as a territory (Fuchs et al. 2003). In any case, pre-dispersal seed predation seems to be an important factor explaining the large variability in crop size in this locality. We have also observed very strong herbivory in $P$. quinata by leaf cutting ants; the drastic defoliation they often cause before leaf abscission could further reduce allocation to reproductive structures.

Recruitment of this species under a continuous canopy is basically negligible as a consequence of seedling mortality. Like in many other wind-dispersed tropical trees, there are limitations to seed dispersal: most seeds are dispersed within $50 \mathrm{~m}$ from the parental tree and in one prevalent direction (Augspurger \& Kitajima 1992, Clark et al. 2005). The seeds germinate soon after there was water available, even in the dark, but only those that land in a forest gap or open canopy site reach the sapling stage. Seeds are quite small and reserves for growth or disease resistance are probably spent within a few days. Our experiments and observations provide no evidence for distance- or density-dependence in seedling survival in the forest, because all naturally-dispersed seedlings die within weeks. We did not studied the density variation of transplanted seedlings into light gaps, so we cannot really test the possible influence on mortality of seedling density versus shade intolerance. However, our results are consistent with a recent study that found a correlation between seedling shade intolerance and susceptibility to soil pathogens, independently from density-dependent effects (McCarthy-Neumann \& Kobe 2008).

High mortality at the seedling stage is common in tropical tree species (Augspurger \& Kitajima 1992, Guariguata 2000), and $P$. quinata is not an exception. In this species seedling survival and growth is limited to forest gaps or a thin canopy, where pathogen incidence is drastically reduced. A small number of saplings may remain suppressed in the understory, but the recruitment of this species does not seem to depend on the release of saplings. Instead, it depends on gap formation combined with the presence of reproductive trees nearby. The importance of the local habitat for establishment is further confirmed by the clumped distribution of adult trees in our censuses. The strategy of this species fits the classical category of a 'long-lived pioneer' (Clark \& Clark 1992), and resembles that of a most valuable timber species in the Neotropics, big-leaf mahogany (Swietenia macrophylla), another fast-growing species with high light requirements that occurs in seasonally dry forests along the southern rim of Amazonia (André et al. 2008).

Our results for $P$. quinata at Tinigua suggest a declining population that does not recruit in the current ecological conditions. In fact, hundreds of other tree species show higher seed production and seedling and sapling densities in the area (pers. obs). Hubbell (1979) suggested two possible explanations for populations overrepresented by adult trees. First, the population could be a relict of a once large cohort originated by succession after strong disturbance (e.g., fire or windstorms). However, if this was the case we would expect to find a relatively homogeneous-sized population, but found instead neighboring trees from 70 to $250 \mathrm{~cm}$ in DBH. The second explanation states that particular habitat conditions are necessary for recruitment and that these conditions are rare. This alternative is supported in our study by the highly clumped individuals, potentially related to large forest gaps that act as safe sites (Grime 1977). The distribution of adult trees seems to be associated with steep slopes, where 
the occurrence of large canopy gaps is more likely (pers. obs). Although the location of gaps is difficult to predict (Denslow 1987), in our study site there was higher density along a largest fault up to 65m (Hirabuki 1990), which might have originated in the last 10000 years.

Management practices of this species should leave the adult trees in the few remaining natural populations of $P$. quinata untouched, for two main reasons. In natural conditions it is a very slow recruiting species, which renders it very vulnerable to any type of logging, in both dry (Kammesheidt 1998) and seasonal forests (this study). Logging of populations with an age structure so biased towards adults can lead to near local extinction (Kammesheidt 1998, Schulze et al. 2008b). The second reason is that natural populations are the source of genetic variation, important for a widely cultivated species like $P$. quinata. As opposed to recruitment in natural conditions, $P$. quinata is easy to grow in cultivation, because seeds do not require any pre-germination treatment, plants can be easily propagated vegetatively and grow fast. We suggest that natural populations could be a source of new genets via the transplant of seedlings from below large trees in natural habitats to open areas. This practice will have minimal effects on natural population dynamics because seedlings are unlikely to recruit under low light conditions. For this purpose the protection of enough number of large trees is necessary to guarantee seedling production and high genetic variability (Fuchs et al. 2003).

\section{ACKNOWLEDGMENTS}

We thank Carlos Mejía for continuous support during field work. Ramiro Montealegre shared with us his knowledge on local $P$. quinata. Mauricio Alvarez initially planted the seedlings that served us for two-year monitoring. Financial support was provided by a WCS-FES-Instituto von Humboldt undergraduate research grant to $\mathrm{MCC}$.

\section{RESUMEN}

Información acerca de la historia de vida y reclutamiento de poblaciones naturales de árboles tropicales es escasa, incluso para especies de alto interés comercial. Este estudio se centró en una especie de dosel altamente explotada, Pachira quinata (Malvaceae), en la zona más húmeda de su distribución geográfica, en la Amazonía colombiana. Estudiamos sus patrones fenológicos, producción de semillas y densidades naturales, además de la importancia de la dispersión de semillas y efectos denso-dependientes en el reclutamiento natural, todo lo anterior se logró con el uso de experimentos y observaciones en el campo. En este bosque estacional, la población de $P$. quinata estaba dominada por grandes árboles adultos y el reclutamiento era extremadamente bajo, como consecuencia de la baja producción de frutos, alta depredación de semillas y muy alta mortalidad de plántulas bajo el bosque por infección de patógenos. No encontramos evidencia de efectos de distancia al árbol parental o densidad de semillas en el reclutamiento, pero si hallamos un evidente requerimiento de claros de luz para la supervivencia y el crecimiento de plántulas, donde la mortalidad por patógenos se reduce drásticamente. Sin embargo, a pesar de la dependencia de la luz para la supervivencia, las semillas germinan en la oscuridad. En la zona de estudio, la población de P. quinata parece estar en claro declive, probablemente porque el reclutamiento depende de la coincidencia de la formación de grandes claros con la presencia cercana de árboles reproductivos. Los requerimientos de reclutamiento de esta especie la hacen muy vulnerable a cualquier actividad extractiva de árboles adultos en poblaciones naturales.

Palabras clave: anemocoria, árbol emergente, supervivencia de plántulas, Bombacopsis quinata, Parque Nacional Tinigua.

\section{REFERENCES}

André, T., M.R. Lemes, J. Grogan \& R. Gribel. 2008. Post-logging loss of genetic diversity in a mahogany (Swietenia macrophylla King, Meliaceae) population in Brazilian Amazonia. For. Ecol. Manage. 255: 340-345.

Asner, G.P., D.E. Knapp, E.N. Broadbent, P.J. Oliveira, M. Keller \& J.N. Silva. 2005. Selective logging in the Brazilian Amazon. Science 310: 480-482.

Augspurger, C.K. \& K. Kitajima. 1992. Experimental studies of seedling recruitment from contrasting seed distributions. Ecology 73: 1270-1284. 
Burnham, K.P., D.R. Anderson \& J.L. Laake. 1980. Estimation of density from line transect sampling of biological populations. Wildl. Monogr. 72: 1-202.

Chapman, C.A., R. Wrangham \& L.J. Chapman. 1994. Indices of habitat-wide fruit abundance in tropical forests. Biotropica 26: 160-171.

Clark, C.J., J.R. Poulsen, B.M. Bolker, E.F. Connor \& V.T. Parker. 2005. Comparative seed shadows of bird-, monkey-, and wind-dispersed trees. Ecology 86: 2684-2694.

Clark, D.A. \& D.B. Clark. 1992. Life history diversity of canopy and emergent trees in a Neotropical rain forest. Ecol. Monogr. 62: 315-344.

Cordero, J. \& D.H. Boshier. 2003. Bombacopsis quinata: un árbol maderable para reforestar. Oxford Forestry Institute, Oxford, United Kingdom.

Denslow, J.S. 1987. Tropical rain forest gaps and tree species diversity. Annu. Rev. Ecol. Systemat. 18: 431-451.

Fuchs, E.J., J.A. Lobo \& M. Quesada. 2003. Effects of forest fragmentation and flowering phenology on the reproductive success and mating patterns of the tropical dry forest tree Pachira quinata. Conservat. Biol. 17: 149-157.

Givnish, T.J. 1999. On the causes of gradients in tropical tree diversity. J. Ecol. 87: 193-210.

Grime, J.P. 1977. Evidence for the existence of three primary strategies in plants and its relevance to ecological and evolutionary theory. Am. Nat. 111: 1164-94.

Guariguata, M.R. 2000. Seed and seedling ecology of tree species in neotropical secondary forests: management implications. Ecol. Appl. 10: 145-154.

Guariguata, M.R. \& M.A. Pinard. 1998. Ecological knowledge of regeneration from seed in neotropical forest trees: Implications for natural forest management. Forest. Ecol. Manag. 112: 87-99.

Gutiérrez-Soto, M.V., A. Pacheco \& N.M. Holbrook. 2008. Leaf age and the timing of leaf abscission in two tropical dry forest trees. Trees Struct. Funct. 22: 393-401.

Hirabuki, Y., 1990. Vegetation and landform structure in the study area of La Macarena: A physiognomic investigation. Field Stud. New World Monkeys Macarena Colomb. 3: 35-48.

Hubbell, S.P. 1979. Tree dispersion, abundance, and diversity in a tropical dry forest. Science 203: 1299-1309.
Kammesheidt, L. 1998. Stand structure and spatial pattern of commercial species in logged and unlogged Venezuelan forest. Forest. Ecol. Manag. 109: 163-174.

Kane, M., H. Urueña, W. Dvorak \& C. Atehortúa. 1993. The potential of Bombacopsis quinata as a commercial plantation species. Forest. Ecol. Manag. 56: 99-112.

Lloyd, M. 1967. Mean crowding. J. Anim. Ecol. 36: 1-30.

Lobo, J.A., M. Quesada, K.E. Stoner, E.J Fuchs, Y. Herrerías-Diego, J. Rojas \& G. Saborío. 2003. Factors affecting phenological patterns of bombacaceous trees in seasonal forests in Costa Rica and Mexico. Am. J. Bot. 90: 1054-1063.

Lobo, J., G. Barrantes, M. Castillo, R. Quesada, T. Maldonado, E.J. Fuchs, S. Solís \& M. Quesada. 2007. Effects of selective logging on the abundance, regeneration and short-term survival of Caryocar costaricense (Caryocaceae) and Peltogyne purpurea (Caesalpinaceae), two endemic timber species of southern Central America. Forest. Ecol. Manag. 245: 88-95.

McCarthy-Neumann, S. \& R.K. Kobe. 2008. Tolerance of soil pathogens co-varies with shade tolerance across species of tropical tree seedlings. Ecology 89: 1883-1892.

Nepstad, D.C., A. Verssimo, A. Alencar, C. Nobre, E. Lima, P. Lefevre, P. Schlesinger, C. Potter, P. Mountinho, E. Mendoza, M. Cochrane \& V. Brooks. 1999. Large-scale impoverishment of Amazonian forests by logging and fire. Nature 398: 505-508.

Moret, A.Y., L. Valera, A. Mora, V. Garay, M. Jerez, M. Plonczk, N. Ramírez, \& D. Hernández. 2008. Estructura horizontal y vertical de Pachira quinata (Jacq.) W.S. Alverson, (Bombacaceae) en el bosque universitario "El Caimital", Barinas, Venezuela. Ecotrópicos 21: $62-74$.

Pérez, D., M. Kanninen, F. Matamoros, W. Fonseca \& E. Chaves. 2004. Heartwood, sapwood and bark contents of Bombacopsis quinata in Costa Rica. J. Trop. Forest. Sci. 16: 318-327.

Quesada, M., E.J. Fuchs \& J.A. Lobo. 2001. Pollen load size, reproductive success, and progeny kinship of naturally pollinated flowers of the tropical dry forest tree Pachira quinata (Bombacaceae). Am. J. Bot. 88: 2113-2118.

Ramírez, N., L. Valera, V. Garay, H. Briceño, M. Quijada, Y. Moret de Pena \& J. Montilla. 2008. Eficiencia reproductiva de clones de Pachira quinata (Jacq.) 
W. Alverson (Bombacaceae) bajo condiciones de cultivo. Acta Bot. Venez. 31: 367-386.

Robinett, W.L., C.M. Loveless \& D.A. Jones. 1974. Fieldtests of strip census methods. J. Wildl. Manag. 38: 81-96.

Sandiford, M. 1998. Bombacopsis quinata. In IUCN 2010. IUCN Red List of Threatened Species. (Downloaded: July 2010, www.iucnredlist.org).

Schulze, M., J. Grogan, R.M. Landis \& E. Vidal. 2008a. How rare is too rare to harvest?: management challenges posed by timber species occurring at low densities in the Brazilian Amazon. Forest. Ecol. Manag. 256: 1443-1457.

Schulze, M., J. Grogan, C. Uhl, M. Lentini \& E. Vidal. 2008b. Evaluating ipê (Tabebuia, Bignoniaceae) logging in Amazonia: sustainable management or catalyst for forest degradation?. Biol. Conservat. 141: 2071-2085.

Stevenson, P.R., M. Suescún \& M.J. Quiñones. 2004. Characterization of forest types at the CIEM, Tinigua Park, Colombia. Field Stud. Fauna Flora La Macarena Colomb. 14: 1-20.

Stevenson, P.R., M.C. Castellanos, A.I. Cortés \& A. Link. 2008. Flowering patterns in a seasonal tropical lowland forest in Western Amazonia. Biotropica 40: 559-567.

Urueña, H. \& M.A. Rodríguez. 1988. Contribución al conocimiento de la biología reproductiva de Bombacopsis quinata (Jacq.) Dugand (Malvales: Bombacaceae). Trianea 2: 265-275.

Zar, J.H. 1996. Biostatistical analysis. Prentice- Hall, New York, USA. 